\title{
Management of prairie rangeland
}

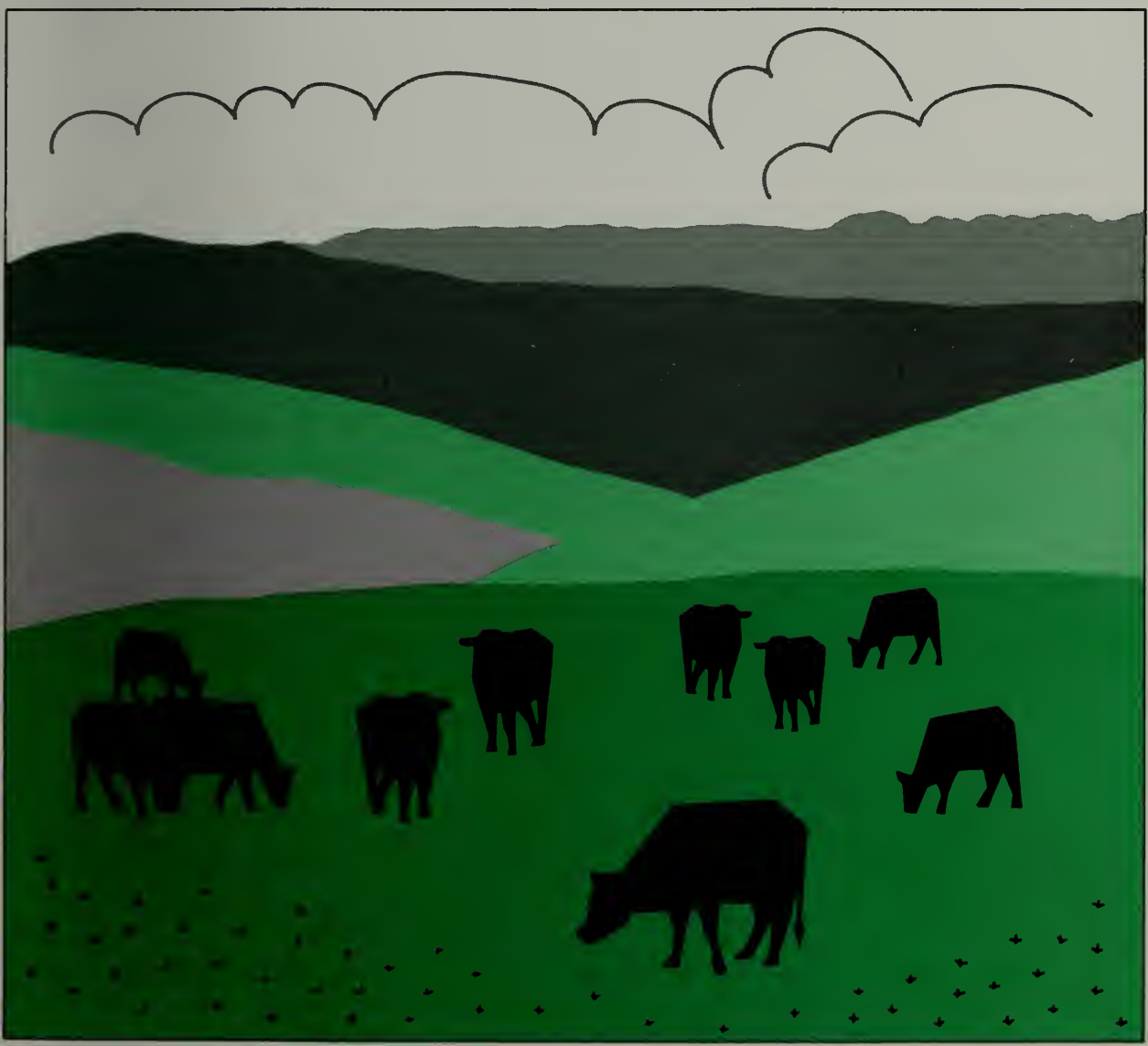





\section{Management of prairie rangeland}

S. Smoliak (retired) and W.D. Willms Research Station

Lethbridge, Alta.

N.W. Holt

Research Station

Swift Current, Sask.

Agriculture Canada Publication 1589/E

available from

Communications Branch, Agriculture Canada

Ottawa K1A 0C7

- Minister of Supply and Services Canada 1990

Cat. No. A53-1589/1989E ISBN 0-662-17126-8

Printed 1976 Revised 1982 Revised 1990 3.5M-01:90

Également disponible en français sous le titre

Gestion des parcours des Prairies 


\section{PREFACE}

Rangelands are an important resource in the production of livestock. About two-thirds of Canada's beef cattle population is raised on about $85 \%$ of the total available rangeland. In addition, about $70 \%$ of Canada's seeded pastures are located in the Prairie Provinces and are used for grazing. Therefore, an understanding of the grasslands is paramount to their proper management.

This publication summarizes available information and experience to serve as a guide to proper range management. Recommendations are based primarily on results of experimental studies since 1927 on rangelands and seeded pastures in southern Alberta and Saskatchewan. Much of this information has been published, although additional unpublished information has also been included.

Most of the work reported was conducted at the Lethbridge research substations near Manyberries and Stavely, Alta., and at the Research Station, Swift Current, Sask. Research to increase and maintain the productivity of rangelands and seeded pastures and to increase beef cattle production is being continued at those locations.

This publication can be used as a guide by ranchers, farmers, range technicians, and public-lands managers to maintain high levels of productivity of rangelands and seeded pastures. A list of references is included at the end of the text for those interested in additional information. 


\section{CONTENTS}

Preface 4

Highlights 6

Introduction 7

Soils and climate 7

Number of livestock and size of pastures 10

Vegetation associations 13

Mixed prairie 14

Fescue prairie 19

True prairie 19

Tall-grass prairie 19

Parkland 20

Management to main tain yield 20

Carrying capacity 21

Carry-over 26

Grazing season 29

Grazing methods 30

Fall pasture 32

Pasture reserves 32

Background material 33

Common and botanical names of plants 35 


\section{HIGHLIGHTS}

- Livestock numbers in the Prairie Provinces reached their average growth potential of 5700000 in about 1920. Since then, cattle have largely replaced sheep and horses, and fluctuations in livestock numbers have followed a cyclical pattern influenced by market conditions: on 1 January 1977, the cattle population peaked at 7700000 but was down to about 6750000 by 1986 .

- Grazing pressure has been reduced, from 2.4 ha per animal unit in 1921 to 2.8 ha in 1986 , by making more efficient use of rangeland and seeded pastures.

- Some 13600000 ha of range and 2500000 ha of seeded pasture are used for grazing. The total area includes Parkland and four types of grassland.

- The principles of good range management apply to all vegetative types. These principles may be applied by slightly different practices in different districts.

- The critical periods in range management occur in early spring, when growth is slow, and in the fall, when the crude protein content of vegetation is less than the amount needed by livestock.

- Seeded forage crops are recommended for complementary grazing. 


\section{INTRODUCTION}

Livestock grazing is one of the main uses of rangeland. The importance of native forage in the production of red meats and other animal products is increasing rapidly as the costs of feed grains and seeded pastures rise.

The management of complex plant communities, such as the prairie rangeland, is concerned with maintaining a balance among species. The balance should be maintained within reasonably narrow limits because, if the balance shifts too far toward undesirable species, it may be difficult to reverse the trend by grazing management alone. Rangeland must also be managed by extensive methods that are ecological, rather than by intensive methods that are agronomic.

The main objective of range management is to maintain the quality of the vegetation and the soil to ensure present and future productivity of the range. An additional objective is to promote plant welfare, because vigorously growing plants yield well and protect the soil. The chief tool of range management is grazing control.

This publication is based on grazing and range vegetation studies and their application to the grasslands and adjacent Parkland of the Prairie Provinces. Relationships among soil, climate, and vegetation and their effect on the growth of grass are discussed.

The spelling of common names of plants is in accordance with the rules in Common and Botanical Names of Weeds in Canada, Agriculture Canada Publication 1397.

\section{SOILS AND CLIMATE}

The prairie rangeland is an eastward-sloping plain between the Rocky Mountains and the Precambrian Shield. The soils are derived mainly from glacial drift deposited by continental ice sheets. The exceptions include an area in southeastern Alberta and southwestern Saskatchewan, where ancient conglomerates, shales, and sandstones are close to the surface, and regions of limestone outcrop in the Interlake district of Manitoba and in central Saskatchewan.

The main soils of the region are Brown, Dark Brown, Black, Gray Luvisol, and high-lime soils (Fig. 1). Brown soils have developed under semiarid conditions. The surface layer is brown and is relatively low in organic matter and nitrogen, the profiles are shallow, and the limy subsoils are close to the surface. Dark Brown soils have developed under less arid conditions. The surface layer is dark brown, the profiles are thicker, and the soils contain more organic matter and nitrogen than the Brown soils. Black soils have developed under still moister conditions; the surface layer is black and rich in organic 


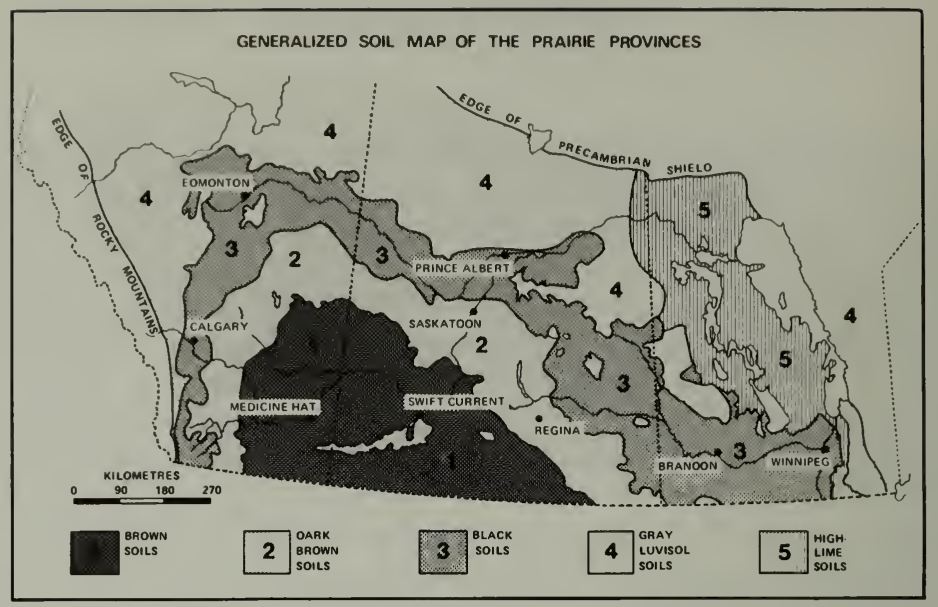

Fig. 1 Generalized soil map of the Prairie Provinces.

matter and nitrogen. The lime layer is usually at depths of $50-75 \mathrm{~cm}$. Gray Luvisol soils occur beyond the Black soils, adjacent to or under a tree cover. Gray Luvisols have an ash-colored, leached surface layer and are low in organic matter and nitrogen. High-lime soils are very shallow, have a high water table, and have developed on extremely limy parent material.

A belt of Solonetzic soils extends across all these soil zones. Solonetzic soils formed from parent material that was high in sodium salts. The subsoil is impervious, and, in some areas, the surface layer has been eroded in patches and has been lost.

Throughout the prairie range, level and moderately rolling tracts of clay, silt, or loam soils are farmed. Steeply rolling areas and eroded, shallow, stony, sandy, or saline soils support native grasses and are used for grazing.

The climate is cool semiarid, merging into cool subhumid in the Parkland. Winters are long and cold, summers are short and warm, and rainfall is low and variable (Table 1).

Long-term precipitation data for three locations are given in Fig. 2. To show trends, the amount of precipitation for each year is the average for that year and the previous 2 years. Fig. 2 shows two points of interest; first, wet and dry years occur in a fairly consistent pattern in all locations. When a drought occurs in one location, conditions are likely to be drier than average in adjacent areas. Therefore, other districts are unlikely to provide extra pasture. Second, years of better-than-average or less-than-average precipitation usually occur in sequence. One wet or dry year affects only the yield, but two or more wet or dry years affect the cover. Drought reduces the abundance of higher-yielding grasses, whereas successive wet years favor their increase. Therefore, the pattern of precipitation causes yields to vary so that forage may either be in short supply or be so plentiful that only a part of the annual growth can be consumed. 
The seasonal duration of adequate rainfall also affects the growth of grass. At the border of the prairies, where precipitation is greater, the period is longer during which summer rainfall is more than $50 \mathrm{~mm}$ per month (Table 1). This longer growing period gives greater assurance of summer pasture. However, north of the North Saskatchewan River, the main factor limiting crop production is the low summer temperature rather than lack of moisture.

Table 1 Long-term weather records from six locations

\begin{tabular}{|c|c|c|c|c|}
\hline \multirow[b]{2}{*}{ Site } & \multicolumn{2}{|c|}{ Precipitation (mm) } & \multirow{2}{*}{$\begin{array}{l}\text { Months with } \\
>50 \mathrm{~mm} \\
\text { rainfall }\end{array}$} & \multirow[b]{2}{*}{$\mathrm{P}: \mathrm{E}^{*}$} \\
\hline & $\begin{array}{l}\text { Mean } \\
\text { annual }\end{array}$ & $\begin{array}{l}\text { May- } \\
\text { July }\end{array}$ & & \\
\hline Brandon, Man. & 471 & 201 & June-August & 1.2 \\
\hline Lacombe, Alta. & 443 & 201 & May-August & 1.2 \\
\hline Lethbridge, Alta. & 423 & 172 & May, June & 0.7 \\
\hline Swift Current, Sask. & 360 & 166 & June & 0.5 \\
\hline Scott, Sask. & 351 & 153 & June, July & 0.6 \\
\hline Manyberries, Alta. & 323 & 134 & June & 0.4 \\
\hline
\end{tabular}

* $\mathrm{P}: \mathrm{E}=$ ratio of precipitation (annual) to evaporation (April-August).

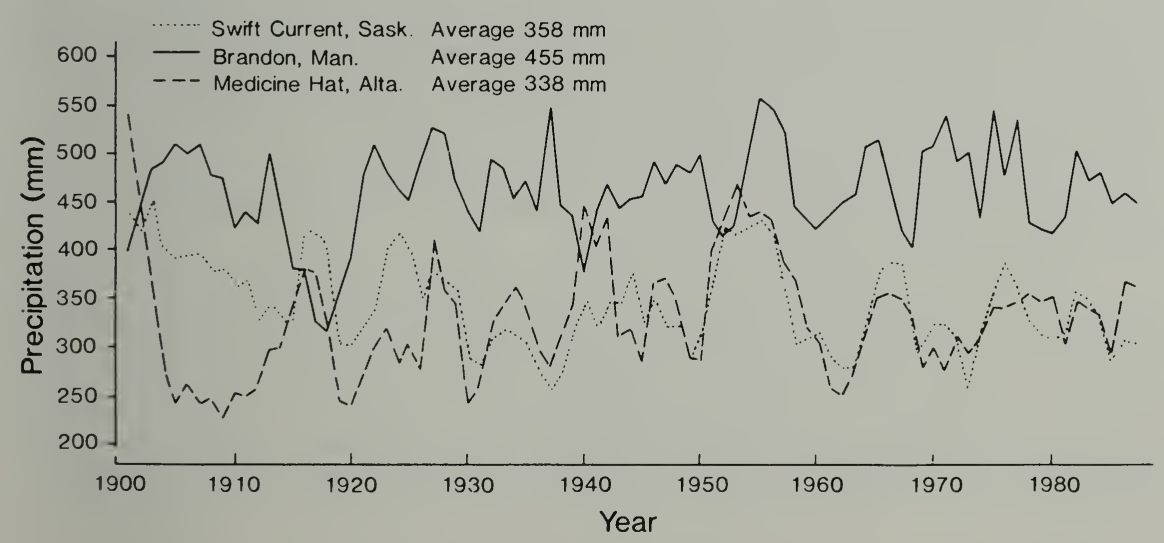

Fig. 2 Average precipitation at three locations in the Prairie Provinces. The amount shown for each year is the average for that year and for the two previous years. 


\section{NUMBER OF LIVESTOCK AND SIZE OF PASTURES}

Beef cattle on the prairies now number about 6750000 (Table 2). The beef cattle population shows two kinds of fluctuations: cyclical and secular. In the early 1900 s, cyclical fluctuations occurred at about 16-year intervals, but more recent cycles have been only about 9 years (Fig. 3). Secular, or long-term, trends are upward, and indications are that they likely will continue.

Sheep have never been important on western ranges. In 1944, the number of sheep reached a peak of 1873000 , but the numbers have decreased steadily ever since. In 1986 sheep numbers were about 257000 (Table 2).

Horses increased in number until about 1921, when tractors began to replace them on farms and ranches. In 1972, there were 181000 horses in the Prairie Provinces, the lowest population since about 1892 , and they no longer contributed significantly to farm output. By 1986 the number had increased again to about 243000 horses. Fewer sheep and horses helped make possible the increase in the number of beef cattle (Table 2).

The total number of animal units appears to have stabilized at about 5700000 (Fig. 4). Cyclical fluctuations of animal numbers after 1930 reflect market conditions as well as forage productivity. Over this period, better management has reduced grazing pressure on native range by including the establishment of seeded pastures and, currently, by placing more emphasis on grazing rotations.

Farmers and ranchers with less than 47 beef cows raised about one-third of the cattle on about three-quarters of the farms in the Prairie Provinces (Table 3). Farmers or ranchers with more than 272 beef cows raised about one-twelfth of the cattle. Smaller farms usually use their range and pasture more efficiently than do larger farms. Generally, larger farms practice a more extensive system of grassland management, whereas small ones make greater use of improved pasture and crop residues.

In 1986, 13600000 ha of native range, 2500000 ha of seeded pasture, and 3300000 ha of hay and fodder (Table 4) provided the feed required for about 6750000 animal units in the Prairie Provinces. Also, an estimated $12 \%$ of the grazing was obtained from stubble fields and crop residues. Over the last 25 years, although available native range has decreased, improved pasture and hay areas have increased. 


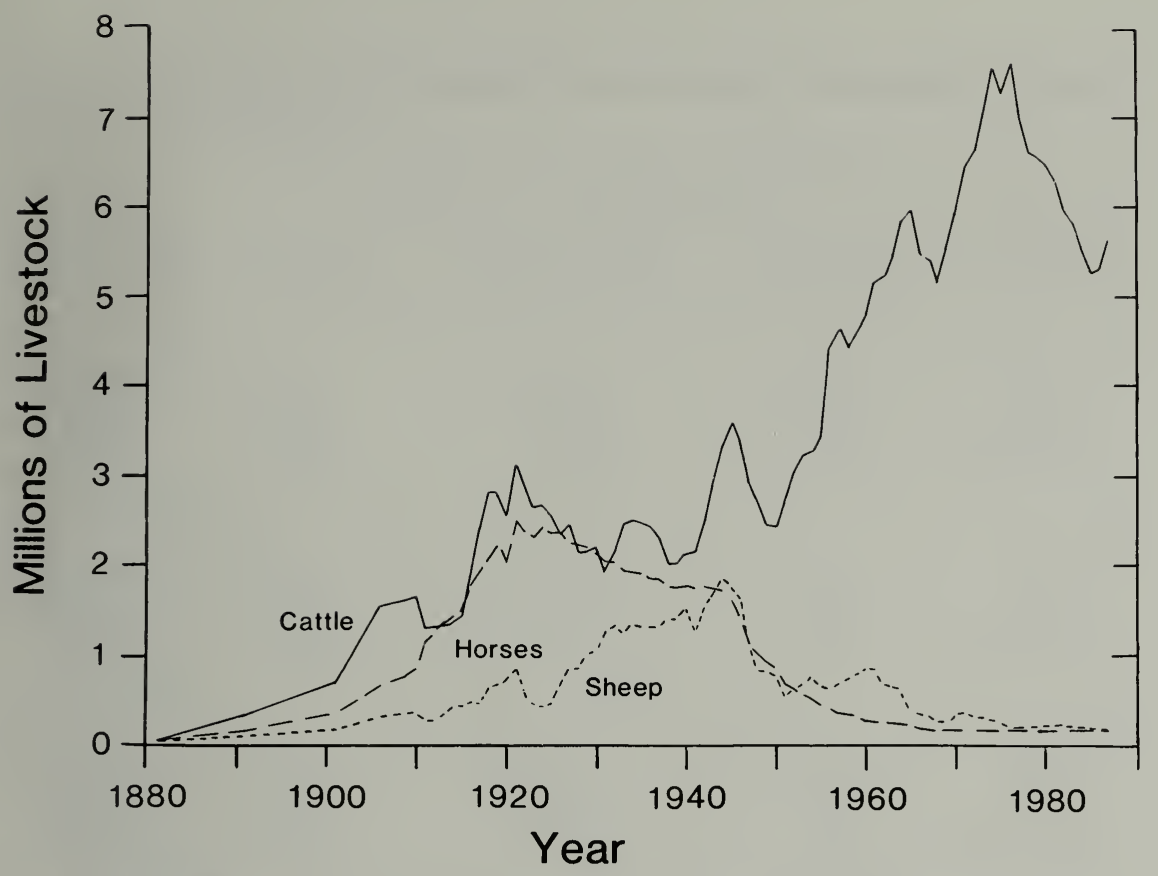

Fig. 3 Number of beef cattle, sheep, and horses in the Prairie Provinces, 18811988 (based on December $\neg$ January inventory).

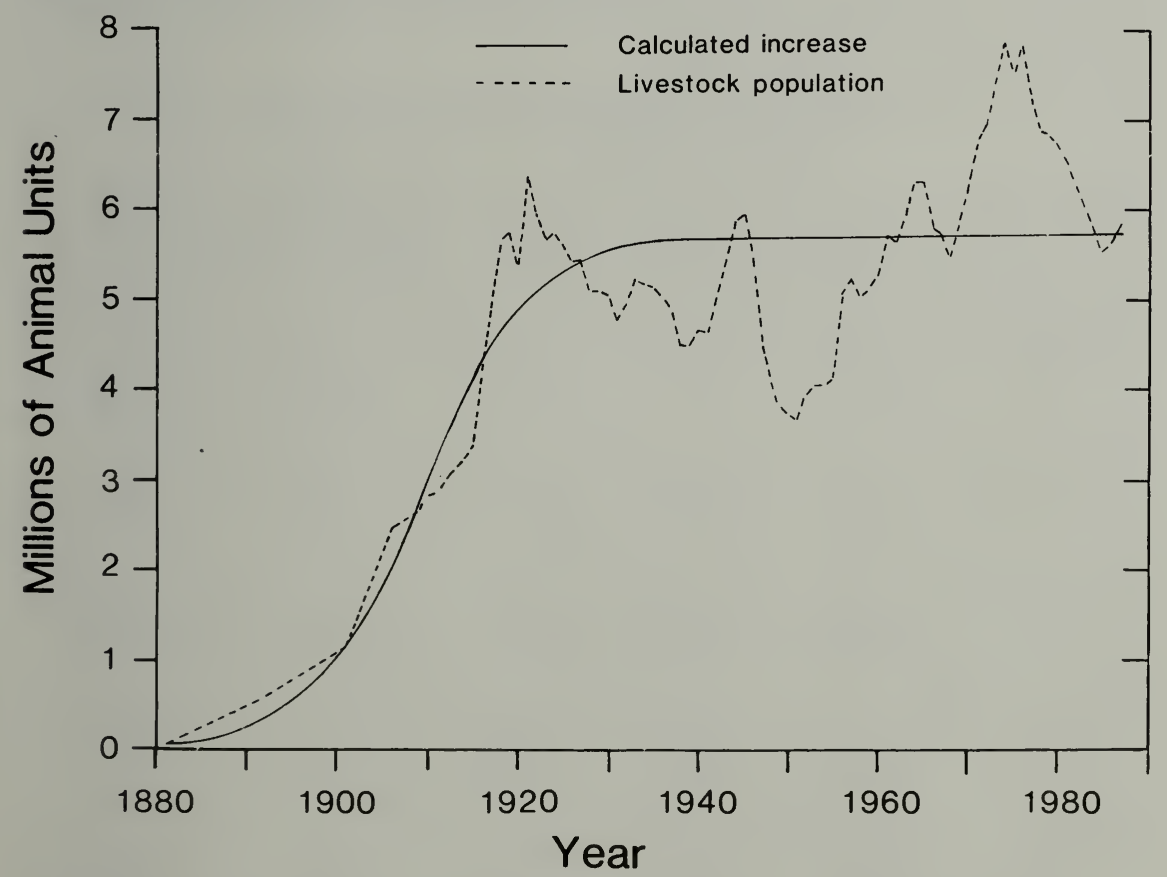

Fig. 4 Actual and calculated growth curves for the livestock population of the Prairie Provinces. Numbers of beef cattle, sheep, and horses are given in animal units (one animal unit equals $1.0 \mathrm{cow}, 5.0$ sheep, or 0.8 horse). 
Table 2 Beef cattle, horses, and sheep in the Prairie Provinces

\begin{tabular}{|c|c|c|c|c|}
\hline \multirow{2}{*}{$\begin{array}{l}\text { Livestock } \\
\text { population }\end{array}$} & \multicolumn{3}{|c|}{ Numbers by province (in thousands) } & \multirow{2}{*}{$\begin{array}{c}\text { Total } \\
\text { number } \\
\text { (thousands) }\end{array}$} \\
\hline & Alberta & Saskatchewan & Manitoba & \\
\hline \multicolumn{5}{|l|}{ Beef cattle } \\
\hline 1961 & 2522.8 & 1826.6 & 749.8 & 5099.2 \\
\hline 1986 & 3702.9 & 1997.5 & 1049.8 & 6750.2 \\
\hline$\%$ change & +47 & +9 & +40 & +32 \\
\hline \multicolumn{5}{|l|}{ Horses } \\
\hline 1961 & 113.2 & 110.3 & 50.8 & 274.3 \\
\hline 1986 & 135.0 & 67.5 & 40.7 & 243.2 \\
\hline$\%$ change & +19 & -35 & -20 & -11 \\
\hline \multicolumn{5}{|l|}{ Sheep } \\
\hline 1961 & 496.9 & 189.0 & 81.3 & 767.2 \\
\hline 1986 & 179.1 & 53.3 & 24.7 & 257.1 \\
\hline$\%$ change & -64 & -72 & -70 & -66 \\
\hline
\end{tabular}

Table 3 Inventory of farms or ranches and beef cows for herds of various sizes, June 1986

\begin{tabular}{|c|c|c|c|c|c|}
\hline \multirow{2}{*}{ Size of herd } & \multicolumn{3}{|c|}{$\begin{array}{l}\text { Numbers by province } \\
\text { (in thousands) }\end{array}$} & \multirow{2}{*}{$\begin{array}{c}\text { Total } \\
\text { number } \\
\text { (thousands) }\end{array}$} & \multirow{2}{*}{$\begin{array}{l}\% \text { of } \\
\text { total }\end{array}$} \\
\hline & Alta. & Sask. & Man. & & \\
\hline $\begin{array}{c}\text { Less than } 48 \\
\text { Farms } \\
\text { Cows }\end{array}$ & $\begin{array}{r}18.3 \\
356.0\end{array}$ & $\begin{array}{r}17.8 \\
338.1\end{array}$ & $\begin{array}{r}8.1 \\
152.1\end{array}$ & $\begin{array}{r}44.2 \\
846.2\end{array}$ & $\begin{array}{l}72.4 \\
34.3\end{array}$ \\
\hline $\begin{array}{c}48-122 \\
\text { Farms } \\
\text { Cows }\end{array}$ & $\begin{array}{r}7.4 \\
544.0\end{array}$ & $\begin{array}{r}4.1 \\
291.6\end{array}$ & $\begin{array}{r}2.4 \\
167.2\end{array}$ & $\begin{array}{r}13.9 \\
1002.8\end{array}$ & $\begin{array}{l}22.7 \\
40.7\end{array}$ \\
\hline $\begin{array}{c}123-272 \\
\text { Farms } \\
\text { Cows }\end{array}$ & $\begin{array}{r}1.7 \\
279.0\end{array}$ & $\begin{array}{r}0.6 \\
96.5\end{array}$ & $\begin{array}{r}0.3 \\
50.1\end{array}$ & $\begin{array}{r}2.6 \\
425.6\end{array}$ & $\begin{array}{r}4.2 \\
17.3\end{array}$ \\
\hline $\begin{array}{c}\text { More than } 27 \\
\text { Farms } \\
\text { Cows }\end{array}$ & $\begin{array}{rr}2 & 0.3 \\
142.5\end{array}$ & $\begin{array}{r}0.1 \\
39.6\end{array}$ & $\begin{array}{l}0.0 \\
8.8\end{array}$ & $\begin{array}{r}0.4 \\
190.9\end{array}$ & $\begin{array}{l}0.7 \\
7.7\end{array}$ \\
\hline $\begin{array}{l}\text { Total } \\
\text { Farms } \\
\text { Cows }\end{array}$ & $\begin{array}{r}27.7 \\
1321.6\end{array}$ & $\begin{array}{r}22.6 \\
765.8\end{array}$ & $\begin{array}{r}10.8 \\
378.1\end{array}$ & $\begin{array}{r}61.1 \\
2465.5\end{array}$ & $\begin{array}{l}100.0 \\
100.0\end{array}$ \\
\hline
\end{tabular}


Table 4 Areas of native range, improved pasture, and hay in the Prairie Provinces

\begin{tabular}{|c|c|c|c|c|}
\hline \multirow{2}{*}{ Fodder type } & \multicolumn{3}{|c|}{ Area (in thousand hectares) } & \multirow{2}{*}{$\begin{array}{c}\text { Total } \\
\text { area } \\
(000 \text { ha })\end{array}$} \\
\hline & Alberta & Saskatchewan & Manitoba & \\
\hline \multicolumn{5}{|l|}{ Native range } \\
\hline 1961 & 8014 & 7731 & 1908 & 17653 \\
\hline 1986 & 6498 & 5398 & 1714 & 13610 \\
\hline$\%$ change & -19 & -30 & -10 & -23 \\
\hline \multicolumn{5}{|c|}{ Improved pasture } \\
\hline 1961 & 676 & 564 & 291 & 1531 \\
\hline 1986 & 1377 & 879 & 275 & 2531 \\
\hline$\%$ change & +104 & +56 & -5 & +65 \\
\hline \multicolumn{5}{|l|}{$H a y^{*}$} \\
\hline 1961 & 1254 & 638 & 474 & 2366 \\
\hline 1986 & 1884 & 864 & 561 & 3309 \\
\hline$\%$ change & +50 & +35 & +18 & +40 \\
\hline
\end{tabular}

* Includes corn for silage, oat and barley hay, and other fodder crops.

\section{VEGETATION ASSOCIATIONS}

Five vegetation associations are found in the prairie range: Mixed Prairie, Fescue Prairie, True Prairie, Tall-grass Prairie, and Parkland. The grassland merges into Parkland at the western, northern, and eastern margins and at the higher elevations. Groves of aspen poplar distinguish the Parkland, and white spruce increases in abundance northward.

The grasslands differ in species composition and can be identified by their major dominants. Each vegetation type or vegetation association includes two or three dominant species. The main vegetation types that occur in the Mixed Prairie are Stipa-Bouteloua, Stipa-Bouteloua-Agropyron, Stipa-Agropyron, Agropyron-Koeleria, and Bouteloua-Agropyron. Fescue Prairie is dominated by a single species, Festuca scabrella. True Prairie is dominated by StipaSporobolus, and Tall-grass Prairie by Andropogon species. Parkland contains grassland and aspen poplar forest.

Some grasses cure on the stem, retaining their form and a few of their nutrients for several months after growth ceases. Although cured grasses contain little crude protein or phosphorus, they do contain high levels of digestible carbohydrates. Many grasses of the 
Mixed and Fescue prairies cure, whereas few species of the True and Tall-grass prairies do.

\section{MIXED PRAIRIE}

\section{Stipa-Bouteloua type}

The Stipa-Bouteloua vegetation occurs on soils of medium texture in the drier parts of the Brown soil zone. This type also occurs on soils of coarser texture in the Dark Brown soil zone and on sandy loam Solonetzic soils. The type is found where average annual precipitation is $250-350 \mathrm{~mm}$ and the precipitation-to-evaporation ratio is less than 0.4. These dry conditions favor the growth of short grasses. Therefore, this grassland is commonly called the Shortgrass Plains, and experience has shown that it should be used as range.

Needle-and-thread and blue grama have the highest ground cover of the grasses on this type of Mixed Prairie and are dominant (Fig. 5a). Other grasses may dominate locally. Associated grasses are June grass, western wheat grass, and Sandberg's blue grass. Thread-leaved sedge is abundant on eroded sites and hillsides. Abundant forbs are moss phlox and little club-moss. Shrubs include pasture sage and silver sagebrush.

Little club-moss is an important constituent of the vegetation. Sometimes its ground cover exceeds all other species combined and may comprise $10-50 \%$ of the total. It provides no forage, but helps to prevent wind and water erosion and reduces the effects of trampling. Seedlings of grasses readily become established in club-moss stands during years of above-average precipitation but rarely in dry years.

Overgrazing of the Stipa-Bouteloua type reduces the amount of needle-and-thread, June grass, and western wheat grass. Blue grama, Sandberg's blue grass, low sedge, broomweed, plains prickly-pear, moss phlox, and pasture sage may increase.

\section{Stipa-Bouteloua-Agropyron type}

The Stipa-Bouteloua-Agropyron (Fig. 5 b) type occurs on mediumtextured soils developed on undifferentiated glacial till in the moister parts and north-facing slopes of the Brown soil zone and in the drier parts of the Dark Brown soil zone. This type is found where annual precipitation is less than $350 \mathrm{~mm}$ and the precipitation-to-evaporation ratio is about 0.5 . Medium-tall grasses, or midgrasses, are more abundant than in the Stipa-Bouteloua type.

Needle-and-thread, northern porcupine grass, blue grama, and wheat grasses make up about $70 \%$ of the total vegetation. Other grasses are June grass, reed grasses, Sandberg's blue grass, and green needle grass. Low sedge is common. Associated forbs and shrubs are moss phlox, little club-moss, pasture sage, silver sagebrush, and roses. 

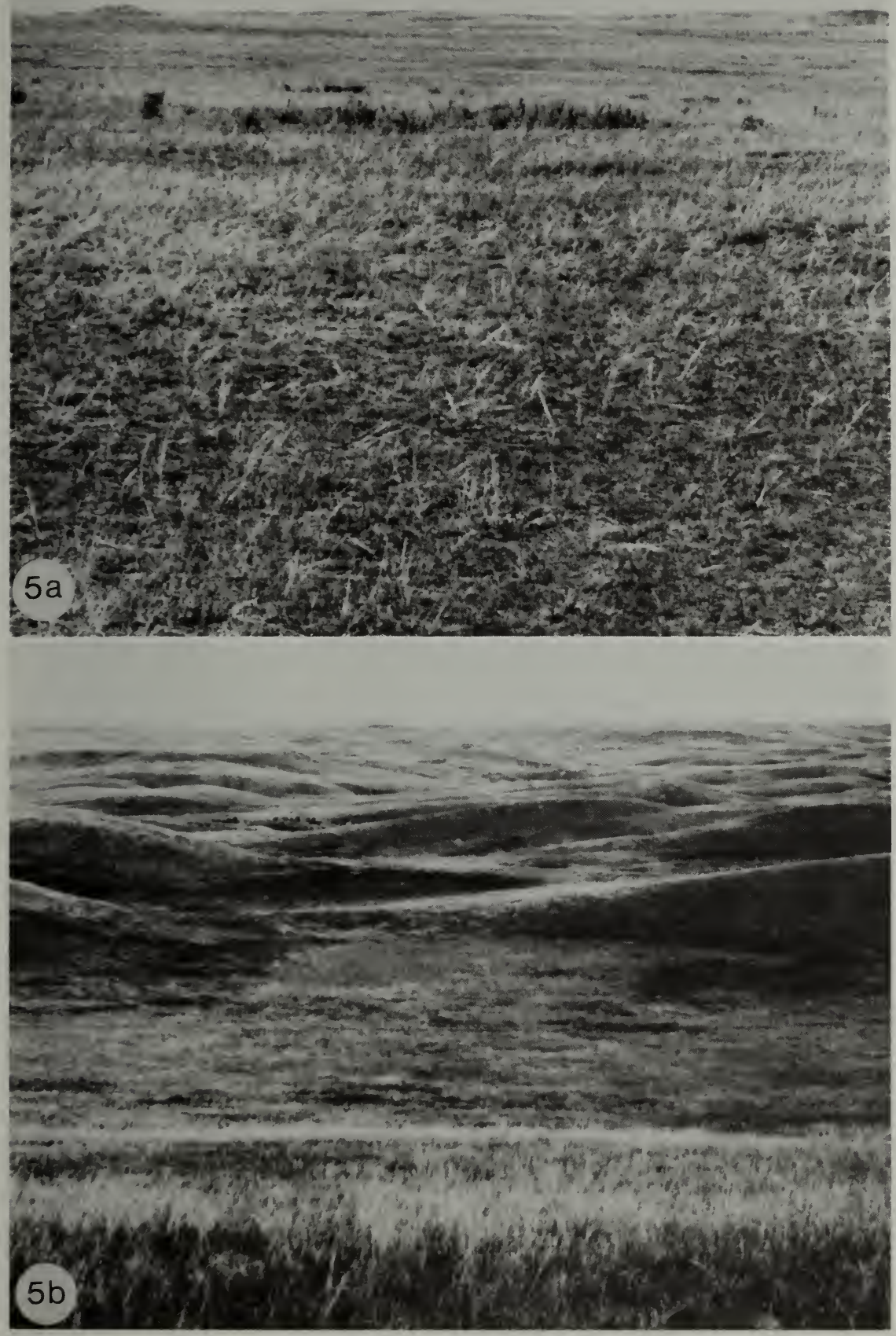

Fig. 5 (a) Stipa-Bouteloua type of Mixed Prairie, commonly called the Shortgrass Plains. (b) Stipa-Bouteloua-Agropyron type. 
With proper management, the midgrasses can be maintained in the stand. The first evidence of overgrazing is the disappearance of the midgrasses and an increase in blue grama. As overgrazing progresses, pasture weeds increase in density, particularly pasture sage, moss phlox, broomweed, little club-moss, and prairie-crocus.

\section{Stipa-Agropyron type}

The Stipa-Agropyron type (Fig. $6 a$ ) occurs on well-developed soils of intermediate texture throughout most of the Dark Brown soil zone and on the adjacent, moister parts of the Brown soil zone. This type occupies rolling topography and sheltered, lower slopes of hills. It is usually transitional between the Mixed and Fescue prairies. It is found in areas where annual precipitation is $350-450 \mathrm{~mm}$ and the precipitation-to-evaporation ratio is $0.5-1.0$.

Important species are northern porcupine grass, needle-andthread, northern wheat grass, and western wheat grass. These species produce $75 \%$ of the total forage. Associated grasses are blue grama, June grass, Sandberg's blue grass, and green needle grass. Low sedge is common. Forbs and shrubs are moss phlox, little club-moss, prairie-crocus, roses, pasture sage, and western snowberry.

Low-growing species such as blue grama, June grass, Sandberg's blue grass, and low sedge, as well as little club-moss, pasture sage, and some shrubs, grow abundantly on overgrazed range. Most of this type is now farmed. Only the hilly, stony, sandy, or rough areas are used for grazing.

\section{Agropyron-Koeleria type}

The Agropyron-Koeleria type occurs in the Brown and Dark Brown soil zones on soils developed on uniform clay deposits that occupy the beds of former glacial lakes. The lacustrine clay soils are desirable for farmland, and only a few areas are used for grazing.

Dominant species are northern and western wheat grasses and June grass, which together produce about $75 \%$ of the forage. Green needle grass, Sandberg's blue grass, and low sedge occur in small amounts. Fewer forbs occur in this type than in others, but moss phlox and pasture sage are common. Winterfat, a forb, is characteristic, but blue grama and needle-and-thread are rare or absent. Wheat grasses, with their creeping roots, are adapted to the shrinking and cracking of clay soils. During drying, the tearing action separates young wheat grass plants from parent plants, whereas it destroys the crowns and roots of grasses with a bunch-type growth habit.

When they are overgrazed, the wheat grasses have less vigor, allowing low-growing plants such as June grass, Sandberg's blue grass, and low sedge to increase in abundance. Weedy forbs and shrubs, such as moss phlox, plains prickly-pear, broomweed, and pasture sage, increase also. 

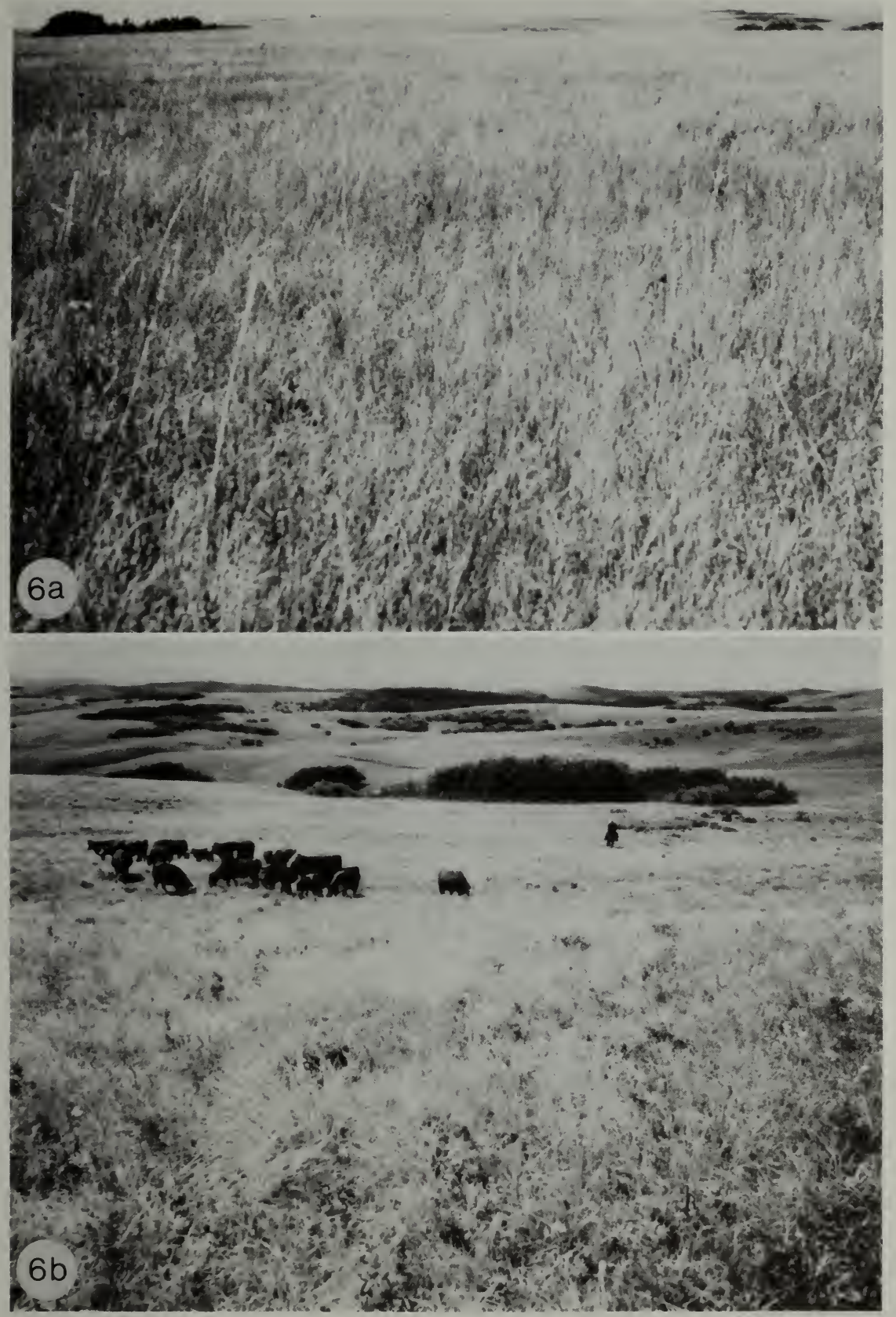

Fig. 6 (a) Stipa-Agropyron type of Mixed Prairie, which is transitional between Mixed Prairie and Fescue Prairie. (b) Fescue Prairie in the foothills of the Rocky Mountains. The nearly continuous grass phase is shown; carrying capacity decreases as trees and shrubs encroach on the grassland. 
The Bouteloua-Agropyron type occurs on light- to heavy-textured Solonetzic soils in the Brown soil zone. During the Solonetzic process, the Ah horizon was removed in burnouts or eroded patches. The somewhat impervious subsoil that was left exposed is suited to the growth of wheat grasses. Where topsoil remains, blue grama is codominant with the wheat grasses.

Western and northern wheat grasses and blue grama provide about $70 \%$ of the forage. Associated grasses are needle-and-thread, June grass, Sandberg's blue grass, and plains reed grass. Forbs and shrubs are moss phlox, little club-moss, plains prickly-pear, silver sagebrush, pasture sage, winterfat, and salt-sage atriplex.

When overgrazed, the midgrasses decrease in abundance, whereas blue grama and Sandberg's blue grass increase. Low sedge, little clubmoss, plains prickly-pear, and pasture sage increase under prolonged heavy grazing.

\section{Other vegetation types}

Throughout the Mixed Prairie, differences in climate, topography, soil depth, soil texture, and salinity, as well as presence or absence of a water table, are shown by the various types of vegetation (Table 5).

\section{Table 5 Examples of important vegetation types and associated soil conditions}

Soil description

Needle-and-thread, blue grama, sand dropseed, sand grass, June grass, and Upland; sandy loam soil northern porcupine grass

Needle-and-thread, sand grass, northern wheat grass, Canada wild rye, sand dropseed, Indian rice grass, and black chokecherry

Desert salt grass, foxtail barley, Nuttall's salt-meadow grass, alkali cord grass, and seaside arrow-grass

Reed grasses, spangletop, manna grasses, prairie muhly, slender wheat grass, tufted hair grass, awned sedge, and slough grass

Western wheat grass, desert salt grass, silver sagebrush, and greasewood

Sandhill prairies; stabilized dune sands

Sloughs and salt meadows; saline soils

Sloughs and marshes; nonsaline soils

Low-lying, level, poorly drained clay soils; saline soils 


\section{FESCUE PRAIRIE}

\section{Festuca scabrella type}

The Festuca scabrella type occurs in the foothills of the Rocky Mountains (Fig. 6b), in the Cypress Hills, on other hilly areas, and over most of the Dark Brown, Black, and Gray Luvisol soil zones in Alberta and Saskatchewan. Only the stony, sandy, or hilly regions are used for grazing; the rest is farmed. This type is found where annual precipitation ranges from 450 to $550 \mathrm{~mm}$ and the precipitation-to-evaporation ratio is about 1.0.

This type is characterized by the presence of rough fescue, which may range from completely dominant along the northern fringe to codominant with northern porcupine grass along the southern edge.

Associated with rough fescue are Parry oat grass (in the southern foothills of the Rocky Mountains only), bluebunch fescue (=Idaho fescue), sheep fescue, wheat grasses, porcupine grass, northern porcupine grass, June grass, and wild oat grass. Forbs are prairiecrocus, silvery lupine, northern bedstraw, and field chickweed. Shrubs, which occur commonly, include shrubby cinquefoil, western snowberry, and roses.

Rough fescue is sensitive to summer grazing and disappears when it is grazed heavily. Therefore, where rough fescue is present in abundance, the range is in good condition. In the southern foothills of the Rocky Mountains, overgrazing results in the replacement of rough fescue by Parry oat grass, bluebunch fescue, wheat grasses, and June grass. Forbs and shrubs that increase include pussytoes, pasture sage, and shrubby cinquefoil. Elsewhere, rough fescue is replaced by wheat grasses, June grass, blue grasses, sedges, and many weeds.

\section{TRUE PRAIRIE}

\section{Stipa-Sporobolus type}

The Stipa-Sporobolus type occurs along the eastern edge of the Mixed Prairie. Most of the land of this type has been plowed and used for production of cereals and forages, except for the high-lime soils of the Interlake district of Manitoba and the sandy soils and areas of rough topography along the Manitoba Escarpment. This type has a high carrying capacity during the growing season. Few of the grasses cure on the stem, and nutritive value of the forage decreases after fall frosts.

\section{TALL-GRASS PRAIRIE}

\section{Andropogon-Sorghastrum type}

Most of this type is now cultivated for cereal, forage, and truck farming. Relict areas show that big bluestem, Indian grass, little 
bluestem, prairie cord grass, porcupine grass, and switch grass were the dominant species. Forbs include northern bedstraw and prairie sage, and shrubs include western snowberry and roses.

\section{PARKLAND}

Parkland is grassland interspersed with groves of aspen poplar; grassland occupies the drier locations and aspen poplar occurs on the moister and more sheltered sites. Parkland is transitional, occurring between prairie and forest. It extends as a fringe along the foothills of the Rocky Mountains in southern Alberta, northeastward as a broad belt across south-central Alberta into Saskatchewan, then southeastward into southwestern Manitoba. The northern part of this vegetative type is mostly forest with occasional patches of grassland, whereas the southern part is mostly grassland with occasional groves of aspen poplar.

In Alberta and Saskatchewan, Parkland developed largely in Fescue Prairie. True Prairie and, to a lesser extent, Mixed and Tall-grass Prairie composed the cover in Manitoba before the invasion of aspen poplar. Parkland has evolved within about the last 150 years.

Tree cover changes gradually from west to east. In the foothills of the Rocky Mountains, lodgepole pine, white spruce, and Douglas fir succeed aspen poplar. Jack pine and balsam poplar are plentiful northward on upland sites, and black spruce grows in low boggy areas. Bur oak, balsam fir, and paper birch increase eastward. The grasses are largely those found in the associations from which Parkland developed, although hairy wild rye grass, slender wheat grass, awned wheat grass, and fringed brome grass are common throughout.

\section{MANAGEMENT TO MAINTAIN YIELD}

Range management is concerned mainly with planning and directing range use to obtain the maximum sustained animal production, as well as the conservation of the natural resources. The principles of range management are as follows:

- Balance the number of animals and the available forage supply.

- Distribute the animals evenly over the range.

- Control the periods of grazing and rest to manage and maintain the vegetation.

- Use the kinds of livestock most suited to the forage supply and the objectives of management.

In range management, an animal unit (AU) is one mature $(450-\mathrm{kg}) \mathrm{cow}$, with or without an unweaned calf, or the equivalent, based on average daily forage consumption of $12 \mathrm{~kg}$ of dry matter per day. An animal unit month (AUM) is the amount of feed or forage 
required by an animal unit for 1 month. Because other classes or kinds of animals eat more or less feed per day than a $450-\mathrm{kg}$ cow, calculations of stocking rates should take into account the difference in their forage requirements. The animal unit also may be adjusted to account for differences in size; for example, a 570-kg cow should represent 1.25 animal units. Animal unit equivalents commonly used in the Prairie Provinces are shown in Table 6.

\section{Table 6 Animal unit equivalents}

Class of animal

Animal unit equivalent

\section{Cattle}

Mature cow, with or without unweaned calf $\quad 1.00$

Weaned calves $\quad 0.50$

Yearling heifers and steers $\quad 0.67$

Bulls, 2 years and older $\quad 1.30$

Horses

Yearlings $\quad 0.75$

2-year-olds $\quad 1.00$

Mature light horses $\quad 1.30$

Sheep

Five ewes, with or without unweaned lambs $\quad 1.00$

Five weaned lambs $\quad 0.50$

\section{CARR YING CAPACITY}

Carrying capacity is a measure of the productivity of the range in terms of the number of hectares needed to supply feed for a mature beef cow or its equivalent. Carrying capacity may be calculated on a monthly or seasonal basis, depending on the productivity of the vegetation. Because vegetation types differ in productivity, they differ also in carrying capacity (Fig. 7).

Within an area dominated by one vegetation type, variations in soils, exposure, and drainage may result in sites with varying forage production because of resultant differences in species composition (Table 7). Also, within an area dominated by one vegetation type, differences in carrying capacity may be caused by variations in condition of vegetation or by climate.

Climatic variation, especially in precipitation, results in high year-to-year variability. At Manyberries, Alta., in the StipaBouteloua type, $164 \mathrm{~mm}$ of rainfall between April and July are needed 


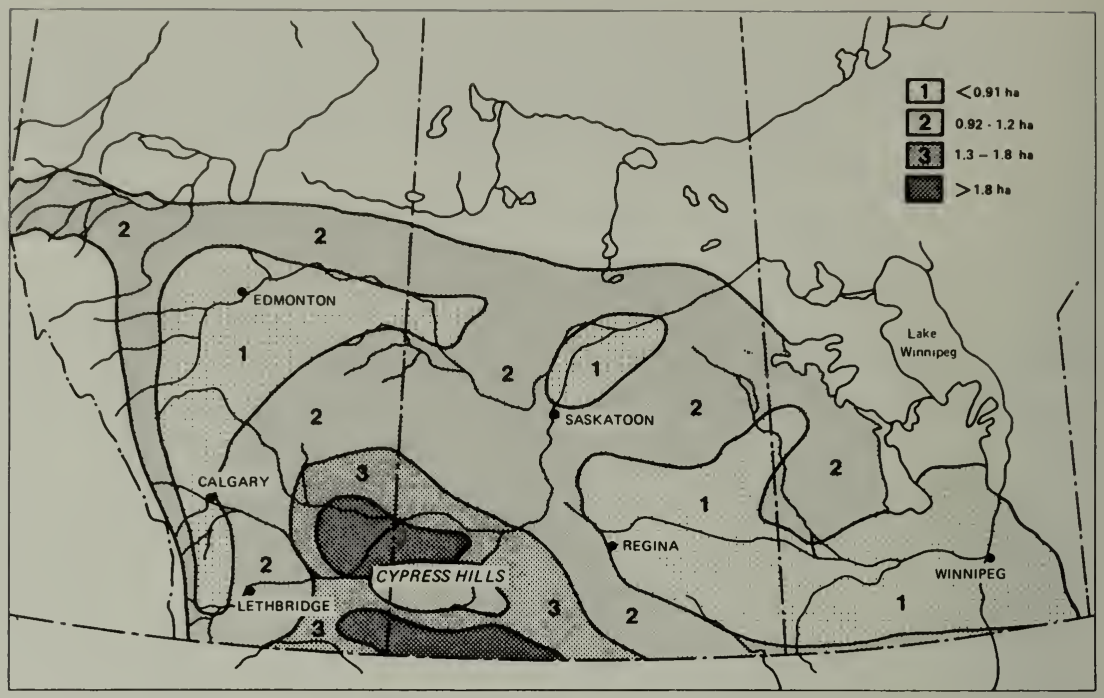

Fig. 7 Carrying capacities, in hectares per animal unit month, of the native grasslands of the Prairie Provinces.

to produce $384 \mathrm{~kg} / \mathrm{ha}$ of forage. The rainfall during this period at Manyberries was $78 \mathrm{~mm}$ in 1961 and $419 \mathrm{~mm}$ in 1965; yields of dry matter were 96 and $736 \mathrm{~kg} / \mathrm{ha}$, respectively. Equations developed from these studies show the relationship between rainfall and yield (Table 8). May plus June rainfall and yield, April rainfall and yield, and soil moisture in the fall and the yield of grass in the succeeding year were found to be closely related.

Based on the regression equation for the Stipa-BoutelouaAgropyron type (Table 8), grass yields in Swift Current, Sask., between 1888 and 1960 were $22-1850 \mathrm{~kg} / \mathrm{ha}$ and averaged $538 \mathrm{~kg} / \mathrm{ha}$. In 27 of the 72 years, there was not enough growth to maintain the livestock load. During 23 years, there was enough grass to meet grazing needs and still provide a carry-over of about $40 \%$. Growth exceeded livestock requirements in only 22 of the 72 years.

Carrying capacity can be determined by experience, by experimental grazing tests, or by estimating forage yield.

To estimate forage yield, the basal ground cover by each species is determined, using the point quadrat method of vegetation analysis, and these data are converted to kilograms of forage per hectare by means of forage yield tables. The sum of the species yields is an estimate of the average total forage yield. Average forage yields also can be determined by clipping sample plots over several years. To allow for carry-over, only $55 \%$ of the total yield is used in calculating the carrying capacity. A $450-\mathrm{kg}$ cow (1 AU) needs about $355 \mathrm{~kg}$ of dry-matter feed per month. Therefore, the number of hectares needed 
to provide feed for a $450-\mathrm{kg}$ cow for 1 month is estimated by the following equation:

Carrying capacity (in hectares per animal unit month) $=355 /(0.55 \times$ kilograms of dry matter per hectare $)$

Table 7 Percentage of basal ground cover, estimated yields, and estimated carrying capacities of three selected vegetation types

\begin{tabular}{|c|c|c|c|c|c|c|}
\hline \multirow{3}{*}{$\begin{array}{l}\text { Plant species } \\
\text { Grasses and Sedges }\end{array}$} & \multicolumn{4}{|c|}{ Mixed Prairie } & \multirow{2}{*}{\multicolumn{2}{|c|}{$\begin{array}{l}\text { Fescue Prairie } \\
\text { Festuca } \\
\text { scabrella } \\
\text { type }\end{array}$}} \\
\hline & \multicolumn{2}{|c|}{$\begin{array}{l}\text { Stipa- } \\
\text { Bouteloua } \\
\text { type }\end{array}$} & \multicolumn{2}{|c|}{$\begin{array}{l}\text { Stipa- } \\
\text { Bouteloua- } \\
\text { Agropyron } \\
\text { type }\end{array}$} & & \\
\hline & & & & & & \\
\hline Needleandthread & 0.7 & 1.3 & $\begin{array}{l}1.0 \\
1.4\end{array}$ & 0.4 & - & $\overline{-}$ \\
\hline Sandberg's blue grass & 1.0 & 0.8 & 0.5 & & _- & _- \\
\hline June grass & 0.5 & 1.0 & 0.9 & 1.0 & 0.4 & 1.2 \\
\hline Western wheat grass & 1.4 & 0.7 & 0.7 & 0.6 & 1.6 & 0.7 \\
\hline Sunloving sedge & 0.5 & 1.7 & 1.5 & 1.6 & 1.3 & 2.2 \\
\hline Northern porcupine grass & - & - & 1.9 & 2.4 & 1.6 & 0.1 \\
\hline Northern wheat grass & - & - & 0.8 & 0.5 & 1.1 & 0.6 \\
\hline Rough fescue & - & - & 0.5 & 1.6 & 3.2 & 4.6 \\
\hline Bluebunch fescue & - & - & - & - & 0.1 & 1.1 \\
\hline Parry oat grass & - & - & - & - & - & 5.0 \\
\hline $\begin{array}{l}\text { Other grasses and } \\
\text { sedges }\end{array}$ & 0.4 & 1.1 & 1.1 & 0.4 & 2.1 & 1.2 \\
\hline Forbs and Shrubs & & & & & & \\
\hline Pasture sage & 0.5 & 0.7 & 1.6 & 2.5 & - & - \\
\hline Moss phlox & 0.2 & 0.5 & 0.4 & 0.2 & - & - \\
\hline Little clubmoss & 6.5 & 8.7 & 3.2 & 4.1 & 0.8 & _ \\
\hline Roses & - & - & 0.2 & 0.1 & 0.9 & 0.2 \\
\hline Western snowberry & - & - & 0.1 & 0.1 & 0.4 & 0.2 \\
\hline Threeflowered avens & - & - & - & - & 0.6 & 0.3 \\
\hline Silvery lupine & - & - & - & - & 0.1 & 0.4 \\
\hline Shrubby cinquefoil & _- & - & - & - & 0.2 & 1.3 \\
\hline Other forbs and shrubs & 0.7 & 0.4 & 1.2 & 1.1 & 3.5 & 3.6 \\
\hline
\end{tabular}

Estimated mean annual

yield of dry matter

(kg/ha)

$\begin{array}{llll}350 & 450 & 560 & 730\end{array}$

$900 \quad 1400$

Carrying capacity

(ha/AUM)

$1.8 \quad 1.4$

$1.1 \quad 0.9$

$0.7 \quad 0.4$

* Dash indicates that this plant is absent. 
Table 8 Correlation coefficients $(r)$ and regression equations (RE) showing relationship between rainfall $(x$, in $\mathrm{mm}$ ) and grass yields $(y$, in $\mathrm{kg} / \mathrm{ha})$

\begin{tabular}{|c|c|c|c|c|}
\hline \multirow{3}{*}{$\begin{array}{l}\text { Period of } \\
\text { rainfall }\end{array}$} & \multicolumn{4}{|c|}{ Vegetation type } \\
\hline & \multicolumn{2}{|c|}{ Stipa-Bouteloua } & \multicolumn{2}{|c|}{ Stipa-Bouteloua-Agropyron } \\
\hline & $r$ & $\mathrm{RE}$ & $r$ & $\mathrm{RE}$ \\
\hline April & 0.40 & $y=314+2.5 x$ & 0.03 & $*$ \\
\hline May, June & 0.58 & $y=187+2.0 x$ & 0.74 & $1+5.2 x$ \\
\hline April-July & 0.74 & $y=72+1.9 x$ & 0.90 & $y=-269+4.6 x$ \\
\hline
\end{tabular}

* No value to the regression equation.

The carrying capacity of the Stipa-Bouteloua type of Mixed Prairie has been determined by grazing tests at Manyberries, Alta. Fields were stocked at three grazing rates: $16.2,12.2$, and 8.1 ha per animal unit for 7 months of summer grazing. The appropriate grazing capacity was slightly more than 12.2 ha per head. Subsequent grazing studies showed that 14.0 ha of range provided enough feed for a cow and calf over a 7-month grazing season with sufficient carry-over to maintain a stable vegetative cover. In addition, four grazing rates on Fescue Prairie were tested at Stavely, Alta.: 4.8, 3.6, 2.4, and 1.2 ha per animal unit for 6 months of summer grazing. Enough feed for a cow and calf, with sufficient carry-over, was provided by 3.6 ha of range.

Measurements of plant cover for various rates of grazing of Fescue Prairie showed that rough fescue was greatly reduced under heavy and very heavy grazing (Table 9). As the productive grasses disappeared, shrubs and weeds increased. These changes increased runoff, caused soil erosion, and reduced yields.

Carrying capacity is affected by the condition of the range. For example, the Stipa-Bouteloua type varied in carrying capacity from 1.5 to 3.8 ha per animal unit month, depending on the condition of the range (Table 10).

Carrying capacity is also reflected in livestock gain per hectare. Yields of animal products and actual gains from grazing tests in various locations in the Mixed and Fescue prairies are given in Table 11. The range of estimated gain per hectare allows for differences in the productivity of vegetation from place to place. When allowances are made for this variation in productivity, there is a close relationship between estimated and actual beef yields. 
Table 9 Percentage basal ground cover for Fescue Prairie grazed at five rates for a 6-month summer season

\begin{tabular}{lrrrrr}
\hline & \multicolumn{5}{c}{ Rate of grazing } \\
\cline { 2 - 6 } Ground cover (\%) & $\begin{array}{c}\text { Un- } \\
\text { grazed }\end{array}$ & Light & $\begin{array}{c}\text { Moder- } \\
\text { ate }\end{array}$ & Heavy & $\begin{array}{c}\text { Very } \\
\text { heavy }\end{array}$ \\
\hline Parry oat grass & 5.4 & 5.9 & 7.5 & 10.7 & 7.6 \\
Rough fescue & 10.1 & 9.1 & 4.8 & 1.8 & 0.5 \\
Bluebunch fescue & 1.2 & 1.2 & 1.3 & 2.8 & 2.6 \\
Other grasses & 1.2 & 0.5 & 0.9 & 0.5 & 0.7 \\
Sedges & 0.1 & 0.6 & 0.9 & 1.4 & 2.1 \\
Forbs and shrubs & 4.4 & 6.6 & 7.6 & 5.5 & 8.0 \\
Total ground cover & 22.9 & 24.0 & 23.3 & 22.7 & 21.5 \\
\hline Estimated yield of & & & & & \\
dry matter (kg/ha) & 2100 & 2199 & 2171 & 1865 & 1170 \\
\hline
\end{tabular}

Table 10 Carrying capacity (in hectares per animal unit) as influenced by condition of range

\begin{tabular}{lcccc}
\hline & \multicolumn{4}{c}{ Condition class } \\
\cline { 2 - 5 } Vegetation type & Excellent & Good & Fair & Poor \\
\hline Stipa-Bouteloua & 1.5 & 2.0 & 2.5 & 3.8 \\
Stipa-Bouteloua- & & & & \\
$\quad$ Agropyron & 1.1 & 1.3 & 1.7 & 2.5 \\
Agropyron-Koeleria & 0.8 & 1.1 & 1.5 & 2.0 \\
Stipa-Agropyron & 0.8 & 1.0 & 1.3 & 1.7 \\
Festuca scabrella & 0.5 & 0.6 & 0.8 & 1.1 \\
\hline
\end{tabular}


Table 11 Yields of animal products (in kilograms per hectare) in grazing tests and by estimate

\begin{tabular}{|c|c|c|c|c|c|}
\hline \multirow[b]{2}{*}{ Vegetation } & \multicolumn{3}{|c|}{ In grazing tests } & \multicolumn{2}{|c|}{ By estimate } \\
\hline & $\begin{array}{l}\text { earling } \\
\text { ewes }\end{array}$ & Steers & Calves & Steers & Calves \\
\hline $\begin{array}{l}\text { Stipa-Bouteloua } \\
\text { Stipa-Bouteloua- }\end{array}$ & 9 & 18 & $11-16$ & $15-19$ & $11-18$ \\
\hline Agropyron & $-*$ & 21 & - & $13-25$ & $15-28$ \\
\hline Festuca scabrella & - & - & $39-45$ & $26-44$ & $28-50$ \\
\hline Crested wheat grass & 24 & 56 & - & $34-56$ & - \\
\hline Russian wild rye grass & S 29 & 73 & - & $39-73$ & - \\
\hline
\end{tabular}

* Dash indicates that no data are available.

\section{CARRY-OVER}

Carry-over is the grass that is left on the ground at the end of the grazing season. On summer ranges, carry-over should be about $45 \%$ of the current year's growth of grass. Carry-over is easily seen and can be used as an indicator of range condition.

Carry-over is necessary because plants manufacture their own food in their green leaves. On summer ranges, about half the leaves should be left to manufacture food reserves, which are stored in the roots and crowns. These food reserves ensure continuing vigor. productivity, and longevity. Carry-over also traps snow and increases soil moisture, protects the crowns of plants, and allows for production of seed.

A carry-over of $45 \%$ every year is an impractical goal. Yields vary widely from year to year, and in a stable livestock operation, carry-over also varies widely. Range is not damaged by overuse during dry years when growth and carry-over are low, because the range will regain vigor during wet years, when growth and carry-over are high. For example, Mixed Prairie range was kept in good condition after 6 years of removing forage, with simulated grazing, to leave carry-over that ranged from 32 to $73 \%$ and averaged $49 \%$. The rancher should aim at a rate of grazing that, over several years, will leave about $45 \%$ of the forage on the ground as carry-over.

Carry-over may not be as important on winter ranges as it is on summer ranges, because all the necessary food has already been stored in the roots and crowns before grazing starts. Therefore, stocking rates may be increased if grazing is limited to the winter season. However, on many ranges water limits forage production. Where this happens, carry-over is very important, regardless of when the range is grazed, because it produces litter that insulates the soil, reduces evaporation, and thus increases available moisture to the 
plant. On the Mixed Prairie, removing all carry-over in fall resulted in a $60 \%$ reduction in subsequent forage yield. Carry-over can be less than $45 \%$ on seeded pastures, because seeded grasses can tolerate more foliage removal than can native grasses.

The value of carry-over has been shown by the clipping of rough fescue plants (Fig. 8). Tiller production, root weight, and forage production decreased as clipping intensities were increased (Table 12). Similar decreases occurred when needle-and-thread was clipped too closely and too frequently (Table 13).

Grazing may change the composition of a sward. In Mixed Prairie, needle-and-thread commonly becomes more abundant when a carry-over of about $45 \%$ or more is maintained. But low-yielding plants such as blue grama and thread-leaved sedge, or weedy plants such as pasture sage, become more abundant when grazing is intensified. The variation in percent composition of Mixed Prairie pastures after 10 years of grazing is shown in Table 14 .

Table 12 Tillering and weight of roots and leaves of rough fescue clipped to three heights every 4 weeks for 20 weeks

\begin{tabular}{lccccr}
\hline & \multicolumn{2}{c}{ Number of tillers } & & \multicolumn{2}{c}{$\begin{array}{c}\text { Weight of } 10 \text { plants } \\
\text { at end of test (g) }\end{array}$} \\
\cline { 2 - 3 } \cline { 5 - 6 } Treatment & $\begin{array}{c}\text { At start } \\
\text { of test }\end{array}$ & $\begin{array}{c}\text { At end } \\
\text { of test }\end{array}$ & & Roots & Leaves \\
\hline Not clipped & 87 & 431 & & 147 & 202 \\
Clipped to $12.5 \mathrm{~cm}$ & 77 & 427 & & 78 & 160 \\
Clipped to $7.5 \mathrm{~cm}$ & 81 & 192 & & 30 & 59 \\
Clipped to $3.8 \mathrm{~cm}$ & 73 & 53 & & 7 & 18 \\
\hline
\end{tabular}

Table 13 Annual yields and percentage survival of needle-and-thread when clipped every month for four summers

\begin{tabular}{ccc}
\hline $\begin{array}{c}\text { Percentage } \\
\text { clipped }\end{array}$ & $\begin{array}{c}\text { Yield per } \\
\text { 100 plants (g) }\end{array}$ & $\begin{array}{c}\text { Plants living } \\
\text { after 4 years (\%) }\end{array}$ \\
\hline 20 & 97 & 100 \\
40 & 96 & 100 \\
60 & 82 & 100 \\
80 & 72 & 77 \\
100 & 60 & 50 \\
\hline
\end{tabular}




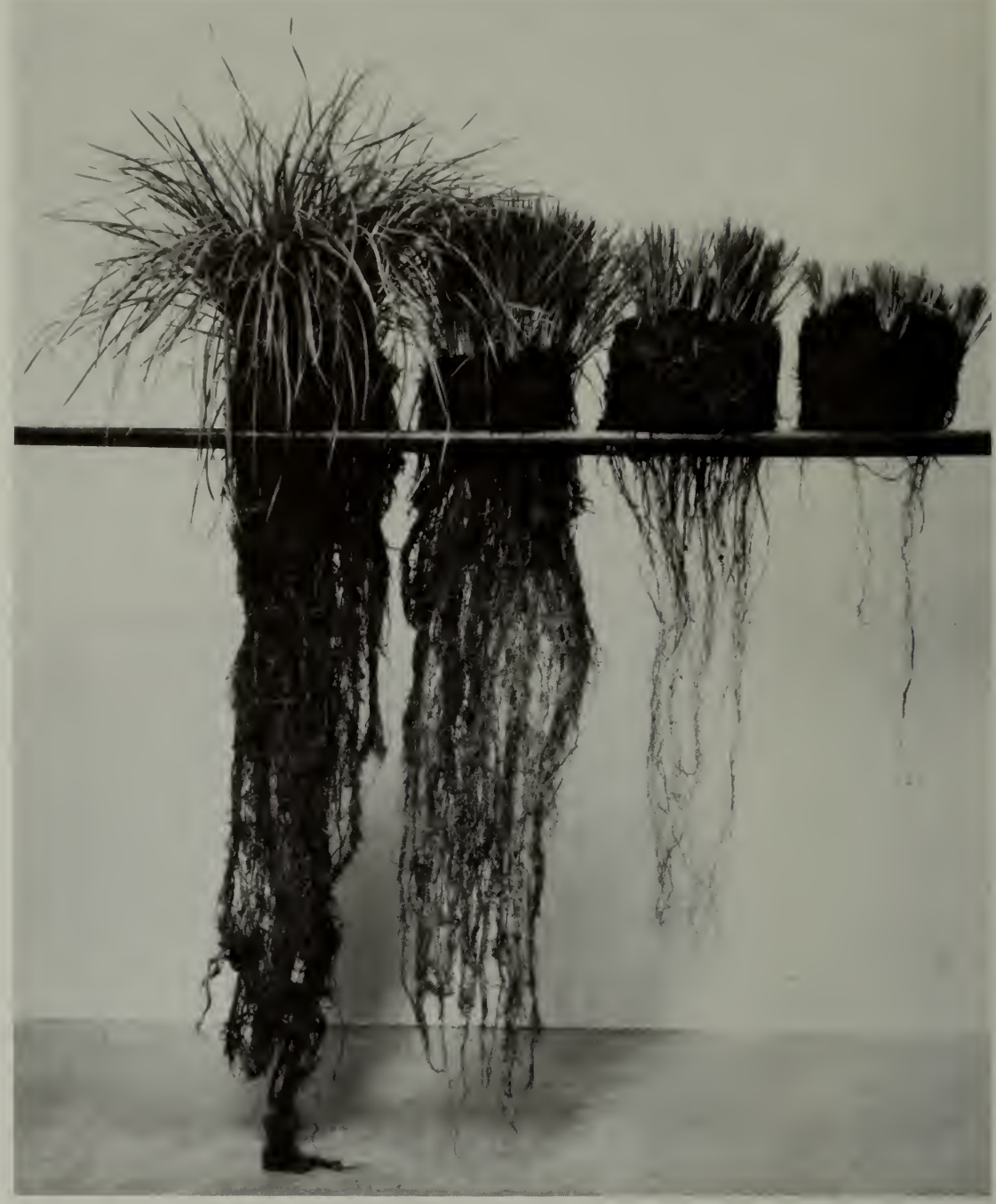

Fig. 8 Sods of rough fescue clipped in the greenhouse at different heights every 4 weeks for 5 months. Left to right: Not clipped; clipped to 12.5, 7.5, and $3.8 \mathrm{~cm}$. The decrease in food reserves is shown by the decrease in root volume as the intensity of clipping is increased. 
Table 14 Percentage composition of Mixed Prairie swards at three grazing intensities

\begin{tabular}{lccc}
\hline Species & $\begin{array}{c}\text { Ungrazed } \\
(\%)\end{array}$ & $\begin{array}{c}\text { Moderately } \\
\text { grazed } \\
(\%)\end{array}$ & $\begin{array}{c}\text { Overgrazed } \\
(\%)\end{array}$ \\
\hline Wheat grasses & 70 & 20 & 10 \\
June grass & 10 & $-*$ & - \\
Needle-and-thread & 20 & 40 & 10 \\
Blue grama & - & 20 & 40 \\
Thread-leaved sedge & - & - & 20 \\
Pasture sage & - & 20 & 20 \\
\hline
\end{tabular}

* Not present in measurable amounts.

\section{GRAZING SEASON}

Two concepts of the term grazing season are recognized. The first is concerned with the safety of the animals. Animals can graze safely from the time that the danger of spring storms is over until snow prevents foraging. This concept of a grazing season provides about 7-10 months in the southern districts, but less than 6 months at the northern limits of the Parkland. The second concept refers to the condition and vigor of the sward. Grazing in the spring should be deferred until the grasses are in the rapid phase of growth and are manufacturing and storing food. Therefore, the date to begin grazing varies from year to year. A more visible sign is when certain well-known plants are in bloom. For the Mixed Prairie, grazing can start when the golden-bean is in full flower, usually late in May. For the Fescue Prairie, grazing should start when the shooting-star flowers.

Grass species start growth at different times. In the Mixed Prairie, the order of growth is Sandberg's blue grass, June grass, western wheat grass, needle-and-thread, northern porcupine grass, and blue grama; the last species is about 6 weeks later than the first. In the Fescue Prairie, the order is rough fescue, Parry oat grass, bluebunch fescue, and wheat grasses; the wheat grasses are about 4 weeks later than the rough fescue. When grasslands are grazed too early in the spring, one or two species carry the load, and their stands and productive capacity are reduced. Growth of most grasses is slow until late May but is fairly fast during June (Fig. 9). Rapid growth begins when the soil temperature at $15 \mathrm{~cm}$ below the surface reaches $10-13^{\circ} \mathrm{C}$. Crested wheat grass and Russian wild rye grass start to grow about 3 weeks earlier in spring than do native grasses and they grow at a much more rapid rate. 


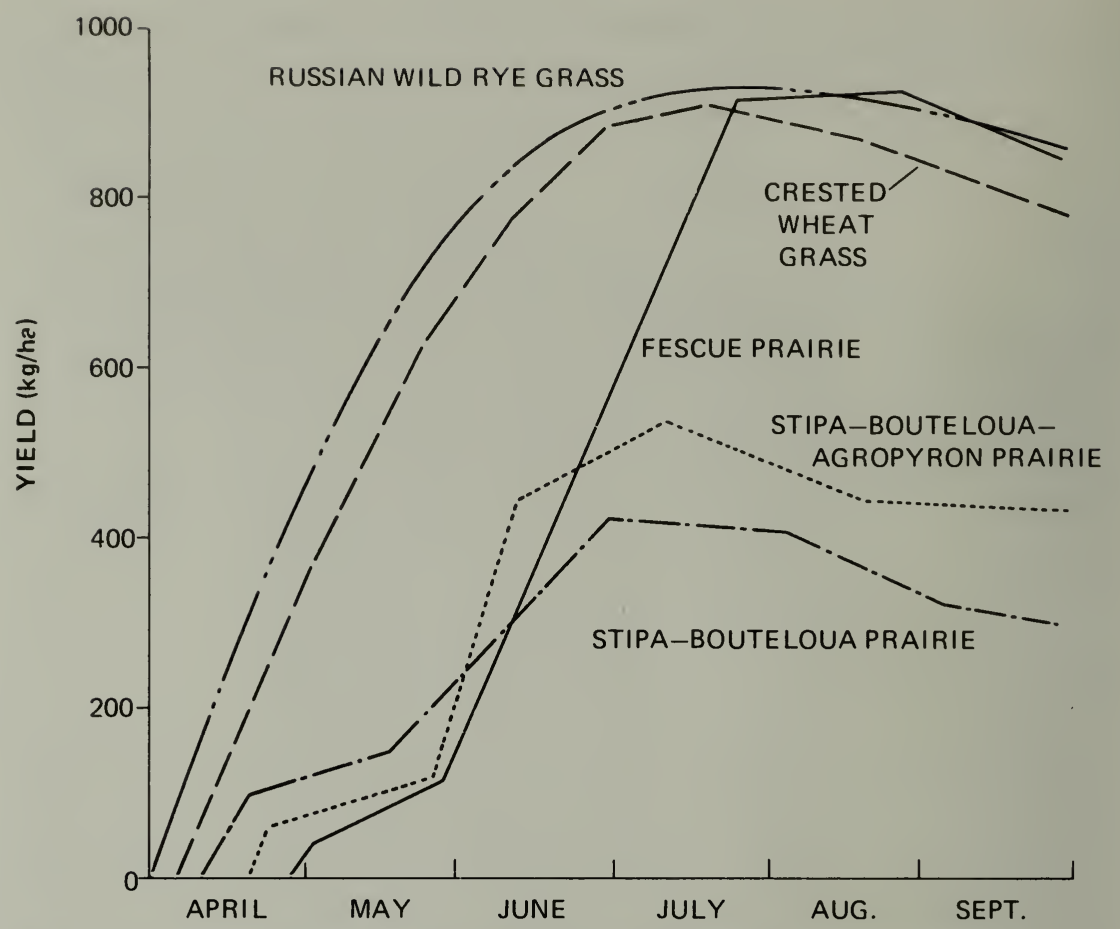

Fig. 9 Average yields of dry matter per hectare from five types of pasture.

On Mixed Prairie, the yield of native forage is greater the longer grazing is delayed in May and June. Simulated grazing tests started in late April, late May, or late June showed that yield was highest when clipping was delayed until late June (Fig. 10).

\section{GRAZING METHODS}

Ranchers can use one of several grazing methods, depending on their own requirements. They can use two main fields, one for summer and the other for winter; subdivide the summer range into two fields and graze each field in rotation in a spring-summer and a summer-fall system; divide the summer range into three fields and use each for about one-third of the grazing season; or divide the range into four or more fields and graze one field while others are left ungrazed for part or all of the growing season.

Some of these systems have been studied in grazing tests. Results show that one field grazed continuously produces animal weight gain as much as or more than two or three fields grazed in rotation at the same rate of stocking. The results were similar on Fescue Prairie, Mixed Prairie, and grass-alfalfa pastures in the Mixed Prairie region (Table 15). However, rotational grazing improves the grass cover because the plants are allowed to set seed and maintain food reserves. 


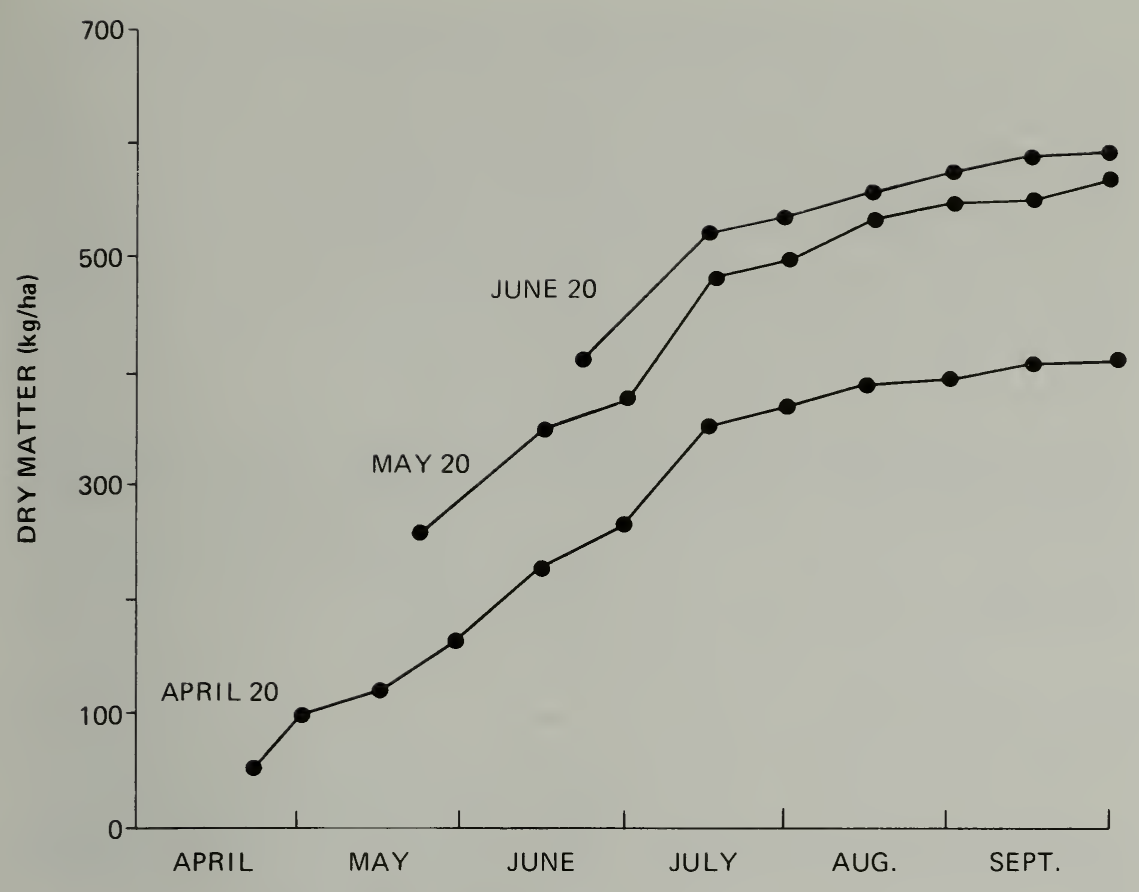

Fig. 10 Average cumulative yields of Mixed Prairie when clipping at 2-week intervals was started on three dates, April 20, May 20, and June 20.

Table 15 Comparison of continuous grazing and three-field deferred rotational grazing

\begin{tabular}{|c|c|c|c|c|}
\hline \multirow[b]{2}{*}{$\begin{array}{l}\text { Pasture } \\
\text { and stock }\end{array}$} & \multicolumn{2}{|c|}{ Liveweight gain $(\mathrm{kg} / \mathrm{ha})$} & \multicolumn{2}{|c|}{ Grass cover $(\%)$} \\
\hline & $\begin{array}{l}\text { Continuous } \\
\text { grazing }\end{array}$ & $\begin{array}{l}\text { Deferred } \\
\text { rotation }\end{array}$ & $\begin{array}{l}\text { Continuous } \\
\text { grazing }\end{array}$ & $\begin{array}{l}\text { Deferred } \\
\text { rotation }\end{array}$ \\
\hline \multicolumn{5}{|l|}{ Mixed Prairie* } \\
\hline Steers & 18 & 17 & 7.2 & 7.4 \\
\hline Calves & 15 & 13 & 7.4 & 8.2 \\
\hline Yearling ewes & 9 & $-\dagger$ & 10.1 & - \\
\hline \multicolumn{5}{|c|}{ Grass-alfalfa pasture $\ddagger$} \\
\hline Yearling ewes & 56 & 47 & 7.3 & 7.6 \\
\hline
\end{tabular}

* Manyberries, Alta.

+ Dash indicates that no data are available.

Swift Current, Sask. 
A test on Mixed Prairie showed the value of grazing crested wheat grass and native range in a complementary system. Crested wheat grass was grazed until late June, and native range from late June to mid October. This system carried $35 \%$ more animals and produced $6 \%$ more daily gain per steer than continuous grazing of native range from May to October. The complementary grazing system resulted in an increased liveweight gain of $43 \%$. Also, the continuously grazed native range was grazed too heavily, but the native range that was protected until late June showed no sign of overuse.

Other tests with complementary grazing systems showed that crested wheat grass may be used until mid June or later, native range from mid June until mid September, and Russian wild rye grass from mid September until November 1. This grazing sequence on Mixed Prairie can be followed by using Altai wild rye grass for 2 months or longer after November 1 . Liveweight production can be doubled by using $20 \%$ of the grazing area in seeded pasture.

\section{FALL PASTURE}

Native grasses are low in protein and phosphorus and high in carbohydrates during the fall. Ranchers overcome the lack of nutritive balance by pasturing cattle on annual cover crops, feeding protein supplements, or providing grass-legume pastures.

A mixture of Russian wild rye grass and alfalfa provides good pasture in the fall in the Brown and Dark Brown soil zones. Fall gains of yearling steers grazed on Russian wild rye-alfalfa were $0.6 \mathrm{~kg}$ per steer per day and, on Mixed Prairie range, $0.3 \mathrm{~kg}$ per steer per day.

Results of a grazing test at Manyberries, Alta., showed that Russian wild rye pasture doubled the live weight gain obtained on adjacent native range. The yearling ewes grazed the seeded pasture for 2.5-3 months in the fall, after mid August.

In the Fescue and True prairies and in the Parkland, red fescue, smooth brome, meadow brome grass, or intermediate or pubescent wheat grasses mixed with a legume are the best pasture crops to complement native range.

\section{PASTURE RESERVES}

Year-round feed reserves are needed. For the most practical means of ensuring feed reserves during spring and summer, maintain the correct carry-over, use moderate rates of stocking, defer grazing in spring, and, especially in the Brown and Dark Brown soil zones, use crested wheat grass or Russian wild rye grass for early season pasture and Russian wild rye grass or Altai wild rye grass for late season and winter pasture. 


\section{BACKGROUND MATERIAL}

Clarke, S.E.; Campbell, J.A.; Campbell, J.B. 1942. An ecological and grazing capacity study of the native grass pastures in southern Alberta, Saskatchewan, and Manitoba. Agric. Can. Publ. 738.

Clarke, S.E.; Tisdale, E.W.; Skoglund, N.A. 1947. The effects of climate and grazing practices on short-grass prairie vegetation in southern Alberta and southwestern Saskatchewan. Agric. Can. Publ. 747.

Coupland, R.T. 1961. A reconsideration of grassland classification in the Northern Great Plains of North America. J. Ecol. 49:135-167.

Coupland, R.T.; Brayshaw, C. 1953. The fescue grassland in Saskatchewan. Ecology 34:386-405.

Lodge, R.W. 1963. Complementary grazing systems for Sandhills of the Northern Great Plains. J. Range Manage. 16:240-244.

Lodge, R.W.; Campbell, J.B. 1965. The point method and forage yield tables for determining carrying capacity. Mimeo. Publ. Agric. Can. Res. Sta., Swift Current, Sask.

Looman, J.; Best, K.F. 1979. Budd's flora of the Canadian Prairie Provinces. Agric. Can. Publ. 1662.

Moss, E.H. 1955. The vegetation of Alberta. Bot. Rev. 21:493-567.

Moss, E.H.; Campbell, J.A. 1947. The fescue grassland in Alberta. Can. J. Res., C. 25:209-227.

Nielsen, K.F., ed. 1969. Proceedings Canadian Forage Crops Symposium. Modern Press, Saskatoon, Sask. 460 pp.

Pigden, W.J. 1953. The relation of lignin, cellulose, protein, starch, and ether extract to the "curing" of range grasses. Can. J. Agr. Sci. 33:364-378.

Smoliak, S. 1968. Grazing studies on native range, crested wheat grass, and Russian wildrye pastures. J. Range Manage. 21:47-50.

Smoliak, S. 1986. Influence of climatic conditions on production of Stipa-Bouteloua prairie over a 50-year period. J. Range Manage. 39:100-103.

Smoliak, S.; Bezeau, L.M. 1967. Chemical composition and in vitro digestibility of range forage plants of the Stipa-Bouteloua prairie. Can. J. Plant Sci. 47:161-167.

Smoliak, S.; Johnston, A. 1980 . Russian wildrye lengthens the grazing season. Rangelands 2:249-250.

Smoliak, S.; Slen, S.B. 1974. Beef production on native range, crested wheat grass, and Russian wildrye pastures. J. Range Manage. 27:433-436. 
Smoliak, S.; Willms, W.D.; Wroe, R.A.; Adams, B.W.; Ehlert, G. 1988. Range pastures in Alberta. Alta. Agric. Agdex 134/14-8.

Wiens, J.K.; Kilcher, M.R. 1971. Winter feed production on graincattle farms in Saskatchewan. Can. Farm Econ. 5(6):20-27.

Willms, W.D.; Smoliak, S.; Dormaar, J.F. 1985. Effects of stocking rate on a Rough Fescue Grassland vegetation. J. Range Manage. 38:220-225.

Willms, W.D.; Smoliak, S.; Schaalje, G.B. 1986. Cattle weight gains in relation to stocking rate on Rough Fescue Grassland. J. Range Manage. 39:182-187. 


\section{COMMON AND BOTANICAL NAMES OF PLANTS}

\section{Grasses}

alkali cord grass

Altai wild rye grass

awned wheat grass

big bluestem

bluebunch fescue

(=Idaho fescue)

blue grama

blue grasses

Canada wild rye crested wheat grass

desert salt grass

foxtail barley

fringed brome grass

green needle grass

hairy wild rye grass

Indian grass

Indian rice grass

intermediate wheat grass

June grass

little bluestem

manna grasses

meadow brome grass

needle-and-thread

northern porcupine grass

northern wheat grass

Nuttall's salt-meadow grass

Parry oat grass

plains reed grass

porcupine grass

prairie cord grass

prairie muhly

pubescent wheat grass

red fescue

reed grasses
Spartina gracilis Trin.

Elymus angustus Trin.

Agropyron trachycaulum var.

unilaterale (Cassidy) Malte

Andropogon gerardi Vitm.

Festuca idahoensis Elmer

Bouteloua gracilis (H.B.K.) Lag.

Poa spp.

Elymus canadensis L.

Agropyron cristatum (L.) Gaertn.

Distichlis stricta (Torr.) Rydb.

Hordeum jubatum L.

Bromus ciliatus L.

Stipa viridula Trin.

Elymus innovatus Beal

Sorghastrum nutans (L.) Nash

Oryzopsis hymenoides (Roem. \& Schult.) Ricker

Agropyron intermedium (Host)

Beauv.

Koeleria cristata (L.) Pers.

Andropogon scoparius Michx.

Glyceria spp.

Bromus biebersteinii Roem. \&

Schult.

Stipa comata Trin. \& Rupr.

Stipa spartea Trin. var. curtiseta Hitchc.

Agropyron dasystachyum (Hook.)

Scribn.

Puccinellia nuttalliana (Schult.)

A.S. Hitchc.

Danthonia parryi Scribn.

Calamagrostis montanensis

Scribn.

Stipa spartea Trin.

Spartina pectinata Link

Muhlenbergia cuspidata (Torr.)

Rydb.

Agropyron trichophorum (Link) K.

Richt.

Festuca rubra L.

Calamagrostis spp. 
rough fescue

Russian wild rye grass

Sandberg's blue grass

sand dropseed

sand grass

sheep fescue

slender wheat grass

slough grass

smooth brome

spangletop

switch grass

tufted hair grass

western wheat grass

wild oat grass

\section{Sedges}

awned sedge

low sedge

sun-loving sedge

thread-leaved sedge

Forbs, shrubs, and trees

alfalfa

alsike clover

aspen poplar

balsam fir

balsam poplar

black chokecherry

black spruce

broomweed

bur oak

Douglas fir

field chickweed

golden-bean

greasewood

jack pine
Festuca scabrella Torr.

Elymus junceus Fisch.

Poa sandbergii Vasey

Sporobolus cryptandrus (Torr.) A. Gray

Calamovilfa longifolia (Hook.) Scribn.

Festuca ovina L.

Agropyron trachycaulum (Link)

Malte var. trachycaulum

Beckmannia syzigachne (Steud.)

Fern.

Bromus inermis Leyss.

Scolochloa festucacea (Willd.) Link

Panicum virgatum L.

Deschampsia caespitosa (L.)

Beauv.

Agropyron smithii Rydb.

Danthonia intermedia Vasey
Carex atherodes Spreng.

Carex stenophylla Wahlenb. ssp. eleocharis (Bailey) Hult.

Carex pensylvanica Lam.

Carex filifolia Nutt.
Medicago sativa L.

Trifolium hybridum L.

Populus tremuloides Michx.

Abies balsamea (L.) Mill.

Populus balsamifera L.

Prunus virginiana L. var. melanocarpa (A. Nels.) Sarg.

Picea mariana (Mill.) BSP.

Gutierrezia diversifolia Greene

Quercus macrocarpa Michx.

Pseudotsuga menziesii (Mirb.)

\section{Franco}

Cerastium arvense $\mathrm{L}$.

Thermopsis rhombifolia (Nutt.)

Richards.

Sarcobatus vermiculatus (Hook.)

Torr.

Pinus banksiana Lamb. 
little club-moss

lodgepole pine

moss phlox

northern bedstraw

paper birch

pasture sage

plains prickly-pear

prairie-crocus

prairie sage

pussytoes

roses

salt-sage atriplex

seaside arrow-grass

shooting-star

shrubby cinquefoil

silver sagebrush

silvery lupine

three-flowered avens

western snowberry

white spruce

winterfat
Selaginella densa Rydb.

Pinus contorta Loud. var. latifolia

Engelm.

Phlox hoodii Richards.

Galium boreale $\mathrm{L}$.

Betula papyrifera Marsh.

Artemisia frigida Willd.

Opuntia polyacantha Haw.

Anemone patens L. var.

wolfgangiana (Bess.) Koch

Artemisia ludoviciana Nutt. var. gnaphalodes (Nutt.) T. \& G.

Antennaria spp.

Rosa spp.

Atriplex nuttallii S. Wats.

Triglochin maritima L.

Dodecatheon conjugens Greene

Potentilla fruticosa $\mathrm{L}$.

Artemisia cana Pursh

Lupinus argenteus Pursh

Geum triflorum Pursh

Symphoricarpos occidentalis

Hook.

Picea glauca (Moench) Voss

Eurotia lanata (Pursh) Moq. 


